\title{
Psicologia, Territorialidades e Violências
}

\section{Psychology, Territories and Violence}

\section{Psicología, Territorialidades y Violencia}

\author{
Simone Maria Hüning ${ }^{1}$ \\ ${ }^{1}$ Universidade Federal de Alagoas, AL, Brasil. \\ Anita Guazzelli Bernardes ${ }^{2}$ \\ ${ }^{2}$ Universidade Católica Dom Bosco, MS, Brasil. \\ Carolina dos Reis ${ }^{3}$ \\ ${ }^{3}$ Universidade Federal do Rio Grande do Sul, RS, Brasil.
}

Este dossiê é fruto da articulação entre distintas professoras e professores, pesquisadoras e pesquisadores de diferentes regiões do país e do exterior, que se propõem a pensar coletivamente a nossa atualidade a partir do campo da Psicologia. Colocar nossa atualidade em análise significa, para esses textos que compõem o dossiê, considerar o modo como certas estratégias de governo das condutas vêm tomando forma e produzindo subjetividades. As discussões que se organizam nos textos voltam-se para um exercício de problematização, a partir da Psicologia, das relações entre territorialidades, violências, políticas e subjetividades. A eleição dessas linhas de composição se faz em razão de algumas pistas que constituem os itinerários de pesquisadoras e pesquisadores que se ocupam com o modo como a Psicologia engaja-se nos processos sociais, que engendram o nosso cotidiano.

Pensar a Psicologia e a partir da Psicologia a nossa atualidade significa operar com ferramentas que se tornam quase incontornáveis: territorialidades, violências, políticas e subjetividades. A dimensão incontornável dessas linhas apresenta-se pelo modo como políticas de vida e de morte se encontram, produzindo distintas formas de violência, desmontes, exceções, a partir dos quais se acirra um mundo em que alguns contam mais que outros, que algumas vidas são mais dignas que outras (Butler, 2018).

Territorialidades, violências, políticas e subjetividades tornam-se ferramentas para formas de pensar localizadas e implicadas. São linhas que permitem certos encontros e certos modos de se encontrar, mediante as quais variações nas formas de pensar, compreender e intervir assumem certas singularidades. As singularidades residem nas estratégias em que essas diferentes linhas aparecem nos textos, conversando com políticas públicas, cenas cotidianas, notícias, memórias, experiências que resistem e insistem. As territorialidades, violências, políticas e subjetividades aparecem nos textos como fios condutores de modos de pensar que se encontram. São fios condutores de encontros, pois, além de criarem certas necessidades de diálogos, também empurram para certas zonas de desconfortos. Os textos abordam possibilidades de aproximações e diálogos com pensadoras e pensadores heterogêneos, bem como cenas, memórias, eventos, experiências, que criam campos de tensão, conduzindo a um jogo arriscado de deixar-se de ser o que se é. Isso se faz por um tensionamento dessas linhas que operam às vezes como conceitos, às vezes como problemas/objetos/temas, às vezes como contestações, às vezes como afirmações.

Territorialidades é uma linha que se ocupará da problematização de espacialidades e daquilo que produz: é articulada por diferentes elementos que se tecem como territórios geográficos, políticos, institucionais e simbólicos, arquiteturas, cartografias, percursos, saberes que forjam formas de habitar e viver na atualidade.

As violências aparecem como linhas que compõem nossa atualidade a partir de políticas e investimentos no fazer morrer, apontando para suas dimensões tanto micropolítica quanto 
macropolíticas, mas, especialmente, para aquilo que não podemos ignorar no nosso presente.

Por políticas, o leitor encontrará tanto a afirmação de um posicionamento epistemológico e ético, ou seja, uma política de pesquisa e de produção de conhecimento; quanto problema/objeto/tema que se encontra na interface com as territorialidades, violências e subjetividades.

As subjetividades, na direção das outras três, figuram como um conjunto heterogêneo de práticas de condução de si e do outro que conformam modos de viver e de habitar na nossa atualidade. As subjetividades, assim, são consideradas como o ponto onde se encontram e expressam os efeitos das políticas, das violências e territorialidades.

Em razão disso, o dossiê compõe-se por textos que dialogam com essas quatro linhas transversais: territorialidades, violências, políticas e subjetividades. Além disso, a organização apoiou-se na possibilidade de que a leitura seja feita como a de uma coletânea, pois os textos têm a pretensão, entre si, de constituir deslocamentos e deslizamentos de uns para os outros, de modo a permitir certas densificações, consistências que não se esgotam em um único texto. Certas reflexões mais tímidas em um texto assumirão mais potência em outro. A perspectiva é de criar um plano de composição entre os diferentes artigos que torne possível movimentos que nos provoquem, como ciência e profissão, a localizar a Psicologia naquilo que hoje nos tornou o que somos.

Trazer territorialidades, violências, políticas e subjetividades para a Psicologia é assumir certo modo de afirmação da vida e denúncia das diferentes formas de produção de mortes. A leitura do dossiê, assim, é um exercício de conexões entre distintas formas de argumentação, distintos autores, distintas experiências, que se tornam mais interessantes quando colocados para conversar. Nesse sentido, os artigos não se esgotam em si, são mais proposições de abertura que permitem, como escrito, deslocamentos e edições inéditas ao serem lidos como um coletivo, como produção de um comum.

O exercício feito em cada um dos trabalhos integrantes do dossiê, sejam eles relatos de pesqui- sas ou reflexões teórico-metodológicas, é o de situar conceitos e análises local e temporalmente. Nesse sentido, o contexto político brasileiro atual, que se apresenta com claras ameaças às políticas públicas e à garantia de direitos, ataques às instituições científicas e à própria democracia, permeia e reitera a pertinência das reflexões apresentadas. Tais preocupações são expressas tanto pelos temas em análise, como pelos referenciais e epistemologias utilizadas. É notável, por exemplo, que, se há pouco tempo predominavam análises de temas afins, a partir de uma perspectiva biopolítica (Foucault, 1988; 2008), neste conjunto de textos, embora não se abra mão desse conceito, a ideia de necropolítica (Mbembe, 2016) passa a operar como um elemento teórico importante.

Esses movimentos do campo teórico-epistemológico são também acompanhados por transformações nas estratégias metodológicas da produção de conhecimento em Psicologia. Assim, no enfrentamento aos desmantelamentos produzidos por uma política de morte, propomos também o desmonte dos discursos colonizados e colonizadores da Psicologia (Castro-Gómez, 2005), apostando na potência das reinvenções deste campo de saber, como as que podem ser produzidas entre outros modos, pelos diálogos com o feminismo descolonial (Davis, 2016). Desse modo, em vez de primar por pesquisas que se vinculam à tradição da replicabilidade e da neutralidade, onde deveríamos ser capazes de "encontrar o mesmo" se refizéssemos a pesquisa, valorizamos seu oposto: a singularidade, a análise contingente, situada e atenta para a complexidade. O caráter ético-político da produção de conhecimento é afirmado pela implicação das pesquisas e pesquisadoras e pesquisadores com a produção da vida cotidiana.

O dossiê é um jogo com o comum, com o coletivo em termos de produção de outras modalidades de subjetivação, que apenas podem ser pensadas de formas situadas. As composições entre os textos permitem esse jogo situado, que singulariza modos de pensar e, sobretudo, aquilo com o qual necessariamente precisamos nos ocupar na nossa atualidade.

\section{Referências}

Butler, J. (2018). Quadros de guerra: Quando a vida é passível de luto?. Rio de Janeiro, RJ: Civilização Brasileira. 
Castro-Gómez, S. (2005). Ciências sociais, violência epistêmica e o problema da 'invenção do outro'. In Lander, E. A colonialidade do saber: Eurocentrismo e ciências sociais: Perspectivas latino-americanas (pp. 80-87). Buenos Aires: Consejo Latinoamericano de Ciencias Sociales.

Davis, A. (2016). Mulheres, raça e classe. São Paulo, SP: Boitempo.

Foucault, M. (1988). Direito de morte e poder sobre a vida. In Foucault, M. A História da sexualidade I: A vontade de saber (pp. 126-149 ). Rio de Janeiro, RJ: Graal.

Foucault, M. (2008). Nascimento da biopolítica: Curso ministrado no Collège de France. São Paulo, SP: Martins Fontes. (Originalmente publicado em 1978-1979).

Mbembe, A. (2016). Necropolítica. Arte \& Ensaios, (32): 123-151.

\section{Simone Maria Hüning}

Docente-pesquisadora do Programa de Pós-Graduação em Psicologia da Universidade Federal de Alagoas. Maceió - AL. Brasil.

Email: simone.huning@ip.ufal.br

(D) https://orcid.org/0000-0001-8080-7733

\section{Anita Guazzelli Bernardes}

Professora do Programa de Pós-Graduação em Psicologia da Universidade Católica Dom Bosco. Campo Grande MS. Brasil.

Email: anitabernardes1909@gmail.com

(D) https://orcid.org/0000-0003-4742-6036

\section{Carolina dos Reis}

Professora Adjunta do Programa de Pós-Graduação em Psicologia Social e Institucional da Universidade Federal do Rio Grande do Sul. Porto Alegre - RS. Brasil.

Email: carolinadosreis@gmail.com

$$
\text { https://orcid.org/0000-0001-6482-2677 }
$$

Como citar: Hüning, S. M., Bernardes, A. G., \& Reis, C. (2019). Psicologia, territorialidades e violências. Psicologia: Ciência e Profissão, 39(n.spe 2), 3-5. https://doi.org/10.1590/1982-3703000042019

How to cite: Hüning, S. M., Bernardes, A. G., \& Reis, C. (2019). Psychology, Territories and Violence. Psicologia: Ciência e Profissão, 39(n.spe 2), 3-5. https://doi.org/10.1590/1982-3703000042019

Cómo citar: Hüning, S. M., Bernardes, A. G., \& Reis, C. (2019). Psicología, Territorialidades y Violencia. Psicologia: Ciência e Profissão, 39(n.spe 2), 3-5. https://doi.org/10.1590/1982-3703000042019 